Moon (three days after Last Quarter) rises, Ih. $6 \mathrm{~m}$. ; souths, $7 \mathrm{~h} .59 \mathrm{~m}$.; sets, $15 \mathrm{~h}, 4 \mathrm{~m}$. ; decl. on meridian, $9^{\circ} 3 \mathrm{I}^{\prime} \mathrm{N}$.

\begin{tabular}{|c|c|c|c|c|c|c|c|c|c|}
\hline Planet & & & $\begin{array}{l}\text { ises } \\
\mathrm{m} \text {. }\end{array}$ & & $\begin{array}{l}\text { Souths } \\
\text { h. m. }\end{array}$ & & $\begin{array}{c}\text { Sets } \\
\text { h. m. }\end{array}$ & & cl. on meridian \\
\hline Mercury & $\cdots$ & 5 & I & $\ldots$ & $13 \quad 17$ & $\ldots$ & 2133 & $\ldots$ & $2325 \mathrm{~N}$ \\
\hline Venus ... & $\ldots$ & I & 42 & $\ldots$ & 918 & $\ldots$ & 1654 & $\ldots$ & I7 $22 \mathrm{~N}$. \\
\hline Mars ... & $\ldots$ & I I & 20 & $\ldots$ & 1730 & $\ldots$ & 2340 & $\ldots$ & I I I N. \\
\hline Jupiter... & $\ldots$ & II & I7 & $\ldots$ & 1731 & $\ldots$ & 2345 & $\ldots$ & $23 \mathrm{~N}$. \\
\hline Saturn... & $\ldots$ & 4 & 16 & $\ldots$ & 1226 & $\ldots$ & 2036 & $\ldots$ & $2234 \mathrm{~N}$. \\
\hline
\end{tabular}
$\mathrm{Jun}_{28} \quad \ldots \quad$ h. $\quad$ Io $\quad$ Mars in conjunction with and $0^{\circ} 59^{\prime}$ south

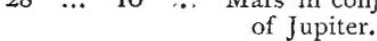

$29 \ldots \quad \circ \quad \ldots \quad$ Venus in conjunction with and $2^{\circ} 57^{\prime}$ north July of the Moon.

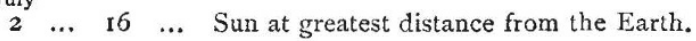

$$
\text { Variable Stars }
$$

Star R.A. Decl.

U Cephei h. m. $8^{\circ}$ ' $\mathrm{N}$... $\mathrm{m}$.

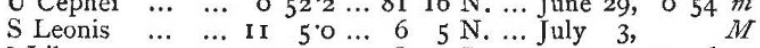

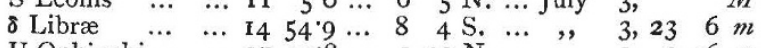

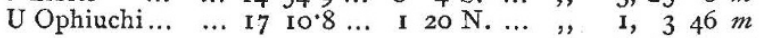

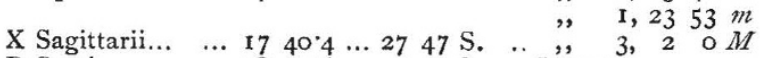

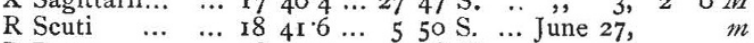

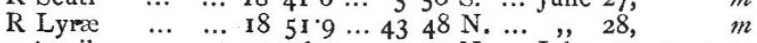

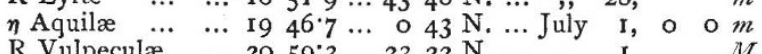

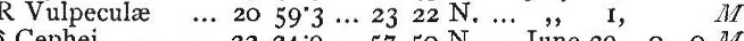

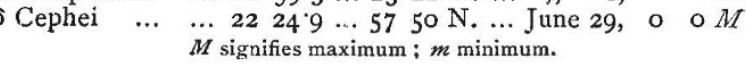

\section{Meteor Showers}

The principal radiants of the season are :-Near $\beta$ Ursæ Majoris, R.A. $164^{\circ}$, Decl. $57^{\circ}$ N. ; near $\zeta$ Ursæ Majoris, R.A. $210^{\circ}$, Decl. $55^{\circ}$ N. ; near $\xi$ Serpentis, R.A. $263^{\circ}$, Decl. $15^{\circ}$ S. ; from Vulpecula, K.A. $302^{\circ}$, Decl. $27^{\circ}$ N. ; near $\zeta$ Pegasi, R. A. $338^{\circ}$, Decl. $13^{\circ} \mathrm{N}$.

\begin{tabular}{|c|c|c|c|c|c|c|}
\hline \multicolumn{7}{|c|}{ Stars with Remarkable Spectra } \\
\hline Name of Star & R.A & A. $1886^{\circ} \circ$ & & cl. $1886^{\circ} \circ$ & & \\
\hline $\mathrm{Aq}$ & $\begin{array}{l}\text { n, } \\
\text { r9 }\end{array}$ & 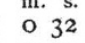 & ... 8 & $34 \mathrm{~N}$. & $\ldots$ & III \\
\hline & ... 19 & 959 & $\ldots$ I 9 & $30.4 \mathrm{~s}$ & $\cdots$ & II \\
\hline erup & ... I9 & & ... 76 & $20 . \mathrm{I} \mathrm{N}$. & $\ldots$ & \\
\hline erup & ... 19 & 2746 & $\ldots 16$ & $37^{\circ} 2 \mathrm{~S}$ & $\ldots$ & \\
\hline & $\cdots$ & 3345 & ... 49 & . & $\ldots$ & \\
\hline M. $+32^{\circ} \cdot 35^{22}$ & $\therefore \quad 19$ & 36 & $\cdots 32$ & $2 I \cdot I N$. & $\ldots$ & I) \\
\hline ... $\quad .$. & ... 19 & $46 \mathrm{II}$ & a. 32 & $37^{\circ}$ & $\ldots$ & \\
\hline $43^{\circ} \cdot 3425$ & ... 19 & 5331 & 43 & $57 \cdot 3$ & $\cdots$ & II \\
\hline $400 I$ & 20 & & & & $\ldots$ & Bright li \\
\hline $35^{\circ} 4002$ & 20 & 66 & & $36^{\circ}$ & $\ldots$ & \\
\hline 4013 & ... 20 & 724 & & $50^{\circ}$ & $\ldots$ & $\mathrm{Br}$ \\
\hline 3956 & 20 & I0 4 & & 17.8 & & $\mathrm{Br}$ \\
\hline 4172 & 20 & 2354 & $\cdots$ & & $\ldots$ & \\
\hline 17.4370 & .. 20 & 3252 & $\cdots+1$ & $52 \circ \mathrm{N}$ & $\ldots$ & I. \\
\hline$\ldots$ & 20 & 3737 & $\cdots$ & $44^{\prime} I$ & & \\
\hline & & & & & & \\
\hline
\end{tabular}

SECOND ANNUAL REPORT OF THE COUNCIL OF THE MARINE BIOLOGICAL ASSOCIATION OF THE UNITED KINGDOM ${ }^{1}$

I. THE Council has met during the past year nine times, 1 viz. on October 5, October 27, December 14, March 19, March 25, April 5, April 9, May 19, and June 7. The chief business which has occupied the Council during the past year has been the preparation of the plan of the Laboratory building now in course of erection on the Citadel Hill at Plymouth, and the arranging for the execution of this plan by building and engineering firms. Further, the Council has given much time and attention to negotiations with the Lords of Her Majesty's Treasury with regard to a grant in aid of the objects of the Association.

The most important facts which the Council has to communicate to the As-ociation as the result of the year's work are :-

(I) The undertaking on the part of the Lords of the Treasury to submit to Parliament a grant of 5000 ., to be paid in two

I Presented to the Annual General Meeting of the Association on June 8, yearly instalments, and $500 l$. a year for five years, in aid of the objects of the Association ; and

(2) The formal approval by the Council of a contract by Mr. Berry, of Plymouth, to erect the buildings and construct the reservoir of the Plymouth Laboratory at the price of $5902 l$. 16s., and also of a contract by Messrs. Leete, Edwards, and Norman, of London, to construct and fit the aquariums and pumping apparatus for the Plymouth Laboratory at the price of 3000 l.

The excavation of the site on the Citadel Hill at Plymouth is now actually in progress, and the Laboratory will be in all probability ready for occupation by this time next year.

In June I 885 , the Council reported a capital sum of nearly $8000 l$. as definitely promised to the Association, of which 4787 l. was in the hands of the Treasurer.

The Council now has to report a capital sum of ro,oool. available for expenditure on the building and fitting of the Plymouth Laboratory, and in addition an annual income from investments and annual subscriptions of $\mathrm{rool}$. a year. Of the disposable capital sum about 5000 . is in the hands of the Treasurer, whilst the sum of $5000 \%$. is to be paid in two instalments, one in 1886, and one in 1887, by Her Majesty's Treasury.

In June 1885, the Association numbered 277 members, of whon 163 were annual subscribers, the rest having compounded. It now numbers 305 members, of whom 169 are annual subscribers.

Amongst important donations to the Association made during the past year, the Council desire especially to mention the sum of 500 . received from Mr. John Bayly, of Plymouth, who was already a Founder, and is now qualified as a Life Governor of the Association. On hearing that the Council felt it to be necessary to omit certain features in the plan of the Plymouth Laboratory as approved by them, on account of the expense involved, Mr. John Bayly came forward with this munificent donation, and thus enabled the Council to carry out their original design.

II. In reference to the grant from the Treasury, the Council submit, for the information of the members of the Association, the final letter received from the Lords of the Treasury and the answer returned by the Council to that communication.

\section{Treasury Chambers, December 9, 1885}

SIR,-I have laid before the Lords Commissioners of Her Majesty's Treasury your letters of the and and I 3 th ultimo, on the question of the proposed assistance to be given by the Government to the Marine Biological Association of the United Kingdom. Their Lordships have considered the matter very carefully, and they now desire me to inform you that they are prepared to propose to Parliament a grant of $5000 /$. towards the cost of the Laboratory which the Association intends to construct at Plymouth, such grant to be paid in two instalments of 2500 . each, one in 1886.87 , and the other in $1887-88$, and also an annual grant of 500 . for five years, beginning in the year $1887-88$, towards the current expenses of the Laboratory, on the following conditions :-

(I) That the Council of the Association agrees to have its accounts formally audited each year, and to furnish a statement of income and expenditure to the Treasury.

(2) That the Council undertakes to issue at regular intervals (probably half-yearly) a detailed report of the work done in the Plymouth Laboratory, and to furnish the Treasury with such report.

(3) That the Council pledges itself definitely to aim at procuring practical results with regard to the breeding and management of food-fishes.

(4) That the Council undertakes to place space in the Plymouth Laboratory at the disposal of any competent investigator deputed by a recognised authority to carry out any investigation into fish questions for which the Laboratory can give facilities.

I am to add that my Lords will make the necessary provision for these grants in the Estimates for the coming year, but until Parliament shall have sanctioned the grant, it will not be in their power to make any payments to the Association in fulfilment of the above promise of assistance.

In conclusion $I$ am to suggest, with reference to your letter of the 8 th instant, that in future any communications between the Association and the Scotch Fishery Board should be conducted through the Secretary for Scotland.

I have the honour to be, Sir, your obedient servant,

M. W. RIDLEY 
SIR, - I have laid before the Council of the Marine Biological Association your letter of the 7 th inst, and I am instructed by the Council to say that they accept the four conditions mentioned in your letter as those upon which the Lords Commissioners of Her Majesty's Treasury are prepared to propose to Parliament a grant of $5000 \mathrm{l}$., and an annual grant of $500 \mathrm{l}$. a year for five years, in aid of the building and of the current expenses of the Laboratory about to be erected by the Association on Plymouth Sound.

The Council of the Association desire me to express, through you, to my Lords, the gratification, which they experience in receiving this important assistance and mark of confidence from my Lords, and to offer at the same time their thanks to my Lords for the favourable consideration which has been accorded to the request of the Council.

In regard to the term " a recognised authority" used in the fourth condition proposed by my Lords and accepted by the Council, I am directed to say that the Council assumes that a "recognised" authority means a "STATE" recognised authority, such as the Scotch Fishery Board or Her Majesty's Inspectors of Fisheries.

On behalf of the Council of the Marine Biological Association I am accordingly empowered to state-

(I) That the Council arrees to have its accounts formally audited each year, and to furnish a statement of income and expenditure to the Treasury.

(2) That the Council undertakes to issue at regular intervals (probably half-yearly) a detailed report of the work done in the Plymouth Laboratory, and to furnish the Treasury with such report.

(3) That the Council pledges itself definitely to aim at procuring practical results with regard to the breeding and management of food-fishes.

(4) That the Council undertakes to place space in the Plymouth Laboratory at the disposal of any c smpetent investigator deputed by a recognised authority to carry out any investigation into fish questions for which the Laborat ory can give facilities.

I have the honour to be, Sir, your obedient servant, E. Ray Lankester, Hon. Sec. M.B.A.

To Sir M. W. Ridley, Bart.

III. The attention of the Council having been drawn to the statement made in the House of Commons by the President of the Board of Trade to the effect that it was the intention of the Government to constitute a Fisheries Department under that Board, the following letter was addressed on March I9 to the President of the Board of Trade :-

$$
\text { April 7, } 1886
$$

SrR,-I am desired by the Council of the Marine Biological Association to inform you that they have observed from an official statement in Parliament that it is the intention of Her Majesty's Government to constitute a Fishery Department as a branch of the Board of Trade. With a view to the meeting of the Council of the Association on March 19 last, I took the liberty to inquire whether you would be disposed to receive a deputation from the Council in order that it might have an opportunity of placing before you some account of the origin of the Association and of its proposed operations with regard to the fisheries of the British seas. The Council having learned that you thought the reception of such a deputation inadvisable, have instructed me to communicate to you, in accordance with your invitation, a brief account of the position of the Association and of its relations to the Government.

The Council have taken steps to erect on the Citadel Hill, at Plymouth, on a site granted by the War Office, a Laboratory, which will be equipped with all the appliances in the shape of tarks and working rooms suited for the study and observation of fishes and other marine organisms. It will afford convenient accommodation for from sixteen to twenty scientific investigators qualified to engage in biological research.

In view of the national utility of such a Laboratory in connection with the fishing industry, the Lords Commissioners of Her Majesty's Treasury have agreed to submit to Parliament a vote of $5 \mathrm{cool}$., in two annual instalments, towards the erection of the Laboratory, and to supplement this when the Laboratory has been completed by an annual subsidy of $500 \mathrm{l}$.

I am directed to aunex for your information a copy of the letter from my Lords embodying these undertakings. You will observe that they have laid stress on the duty of the Association to investigate everything relating to the economy of food fishes, and that they further desired that the Marine Biological Association should work in harmony with the Scotch Fishery Board, which was, at that time, the only formally constituted body connected with the subject in Great Britain.

The Council apprehend, therefore, that the Marine Biological Association, receiving as it does liberal support and recognition of the importance of its aims from the Government, should place at the disposal of the new Fishery Department any resources it may possess for the prosecution of such scientific investigations as the Department may wish to initiate.

The Council further desire me to say that they will be glad to enter into such relations with the Department as may seem to you best calculated to effect the object.

In making this offer the Council believe that they are carrying out the spirit of the conditions imposed upon them by my Lords in the letter of which a copy is inclosed.

I am, Sir, your most obedient servant, E. Ray Lankester, Hon. Sec. M.B.A.

The Right Honourable A. J. Mundella, M.P., Board of Trade

To this letter the following answer was received :Board of Trade, Whitehall Gardens, S. W.,
April 8, 1886

SiR,-I am directed by Mr. Mundella to acknowledge the receipt of your letter of April 7, and to request that you will be so good as to convey to the Council of the Marine Biological Association his best thanks for their kind offer which they have made to place at the disposal of the new Fishery Department the resources which they possess for the prosecution of such scientific investigations as the Department may wish to initiate. Mr. Mundella wishes me to add that the matter is now receiving his most careful consideration.

I am, Sir, your obedient servant,

\section{Prof. E. Ray Lankester \\ T. W. P. BLOMEFIELD}

IV. In reference to the building and aquarium fittings, which have been approved, and are now in course of construction for the Laboratory at Plymouth, the Council appointed, as stated in the last Annual Report, a Committee consisting of the Treasurer, the Secretary, Dr. John Evans, Prof. Moseley, and Mr. Spence bate. These gentlemen, assisted by Mr. Walter Heape, Assistant Secretary, and by Mr. Inglis, civil engineer, of Plymouth, met on several occasions in order to consider the details of the Laboratory building and its fittings. Information and advice was obtained from the directors of the existing laboratories and aquariums in Europe and in the United States of America, as well as from engineering firms acquainted with the special kind of work required. The limitation of the funds at the disposal of the Council had to be strictly borne in mind by the Committee, and finally, after much deliberation, a plan of buildings and fittings was submitted by the Committee and approved by the Council. The approval of the War Office had to be obtained in regard to the design of the building which is to be erected on the site granted by that Department of State, and the Council has had the advantage in this connection of the advice and assistance of Mr. E. Bell, the architect to the War Office. The design, for which a contract has now been accepted by the Council, has the approval of the authorities of the War Office and of the Town Council of Plymouth.

V. Shortly after the annual meeting in June $1885, \mathrm{Mr}$. St. Leger Bunnett, of New Stone Buildings, 6o, Chancery Lane, was appointed Assistant Secretary with the special purpose of aiding the Secretary in obtaining subscriptions and donations.

In January of the present year Mr. Walter Heape vacated his post of Assistant Secretary, and was appointed Resident Superintendent of the Plymouth Laboratory at a salary of 200 l. a year. Mr. Heape will be provided with a suite of apartments in the Laboratory building. Since his appointment Mr. Heape has visited the Zoological Laboratory at Naples for the purpose of acquiring information which may assist him in the management of the Plymouth Laboratory. $\mathrm{He}$ will at once proceed to Plymouth and take up his residence there, in order to commence an investigation of the natural history of Plymouth Sound and to enter into relations with the fishermen of the district, so as to prepare the way for the operations of the Laboratory when completed. Mr. Heape will also watch the erection of the Laboratory building and report from time to time to the Council of the Association at Plymouth.

VI. The Council propose to make two alterations in the 
by-laws of the Association which will require the approval of the present general meeting and of a subsequent special general meeting, which will be duly summoned. 'The first proposal is to enact by by-law of the Association that the Prime Warden of the Fishmongers' Company shall always be ex officio a member of the Council of the Association. 'The Fishmongers' Company have shown their interest in the enterprise of the Association by contributing $2000 l$. to its funds. In reply to an inquiry from the Council, the Court of Assistants of the Fishmongers' Company have cordially accepted the proposition that the Prime Warden of the Company should hold the official relation to the Association above proposed. The Council therefore propose to alter By-law 2 of the Association by the insertion between the words "officers" and "and fourteen other members" of the words "the Prime Warden of the Fishmongers' Company for the time being."

The second proposal has relation to the admission of the Universities of Great Britain and Ireland to a share in the government of the Association. As was stated in the last Annual Report, members of the University of Cambridge have subscribed a sum of $500 \mathrm{l}$. for the purpose of qualifying the University as a Governor of the Association. During the past year a similar fund has been raised by members of the University of Oxford. At the annual general meeting in June 1885 , in view of these proceedings, the following addition to By-law 17 was carried: "Any University of the United Kingdom, on the payment of 500 l. to the Association by members of the University, shall, if the Council of the Association consent thereto, acquire as a consequence the perpetual right of nominating one member of the Council of the Association,"

The Council now propose to erase the words just cited, and to substitute the following :-

"Any University of the United Kingdon, on the payment of $500 /$. to the Association in the name of the University and for the purpose of acquiring the right herein specified, shall, if the Council of the Ass sciation assent thereto, become a Governor of the $\mathrm{A}$ sociation, and acquire the perpetual right of nominating annually one member of the Council of the Association to serve for one year. (from the annual meeting in one year to that in the following year); and any resident member of the University subscribing $\mathrm{IOO} l$. or more to such fund of $500 \%$, shall, in virtue of such subscription, become a 'Founder' of the Association."

VII. The Council have again to record a severe loss to the Association in the list of its Vice-Presidents owing to the death of Dr. W. B. Carpenter, C.B., F.R.S. Dr. Carpenter was a warm supporter of the Association, and contributed largely by his advocacy of its objects to the success which has now been attained.

VIII. The Council do not propose any change in the list of Officers, Vice-Presidents, and Council for the ensuing year. They desire to notify that the following gentlemen have qualified by subscription of 500\% each as Life-Members (Governors) of the Council, viz. Mr. Robert Bayly, of Plymouth, I885; Mr. Bazley White (Clothworkers' Company), 1885; Mr. E. L. Beckwith (Fishmongers' Company), I885; and Mr. John Bayly, of Plymouth, I886.

IX. During the ensuing year the building at Plymouth will be in course of erection. It is anticipated that the chief duty of the Council during this period will be to organise a scheme of investigation to be carried out at Plymouth when the Laboratory is in working order.

It will be especially the business of the Council to determine the conditions under which the Laboratory shall be accessible to the naturalists of the United Kingdom and other countries for the purpose of aiding in those inquiries into the life-history of marine animals and plants, and particularly of food-fishes, which it is the purpose of the Association to foster.

$\mathrm{X}$. The plan of the Laboratory building includes a library. The Council take the present opportunity of asking for donations of works relating to fisheries and to marine zoology and botany for the library. They will also be glad to receive subscriptions towards a special library fund, in reference to which and all similar matters, the Hon. Secretary, Prof. Lankester, can be consulted.

$\mathrm{XI}$. In conclusion, the Council desire again to express the great obligation which the Association is under towards the Council of the Linnean Society for the continued permission accorded by that body to the Association to meet in the rooms of the Society.
MEMORANDUM RELATING TO THE MODE IN WHICH SCIENTIFIC KNOWLEDGE CAN

BE MADE USEFUL TO ENGLISH FISHERIES

THE following Memorandum has been presented to the Presi1 dent of the Board of Trade and officially acknowledged by

Without committing ourselves to all the statements and opinions contained in the subjoined Memorandum, we, the undersigned, wish to state that we concur generally with the views as to the proposed constitution of the new Fishery Department therein expressed-

Argyll, K. G., F. R.S. ; Walsingham ; Stalbridge ; E. Marjoribanks, M.P., Member of the late Royal Commission on Trawling ; John Lubbock, Bart., M.P., F.R.S. ; James Paget, Bart., F.R.S. ; Henry W. Acland, K.C.B., F.R.S. ; J. Fayrer, K.C.S.I., F.R.S., Honorary Physician to the Queen, Physician to the Secretary of State for India in Council ; C. Spence Bate, F.R.S., Member of Council of the Marine Biological Association; I. Bayley Balfour, F.R.S., Sherardian Professor of Botany in the University of Oxford ; Ed. Lonsdale Beckwith, late Prime Warden of the Fishmongers' Company, Member of Council of the Marine Biological Association ; F. Jeffrey Bell, F.Z. S., Professor of Zoology in King's College, London, Member of Council of the Marine Biological Association ; Henry B. Brady, F.R.S. ; W. S. Caine, M.P., Member of the late Royal Commission on Trawlin ; ; P. H. Carpenter, F.R.S. ; W. H. Dallinger, F. R.S., President of the Royal Microscopical Society; F. Darwin, F.R.S. ; W. T. Thiselton Dyer, C.M.G., F.R.S., Director of the Royal Gardens, Kew, Member of Council of the Marine Biological Association; W. H. Flower, F.R.S., Superintendent of the British Museum, Natural History, President of the Zoological Society, Vice-President of the Marine Biological Association; Hans Gadow, Strickland Curator and Lecturer on Animal Morphology in the University of Cambridge; Arthur Gamgee, F.R.S., Fullerian Professor of Physiology in the Royal Institution of Great Britain; W. H. Gaskell, F. R.S. A. Guinther, F.R.S., Keeper of the Zoological Department of the British Museum, Member of Council of the Marine Biological Association; S. F. Harmer, Fellow of King's College, Cambridge; W. A. Herdman, Professor of Zoology in University College, Liverpool, Member of Council of the Marine Biological Association; G. M. Humphry, F.R.S., Professor of Surgery in the University of Cambridge, late Professor of Anatomy, Fellow of King's College; J. N. Langley, F.R S., Fellow of Trinity College, Cambridge; E. Ray Lankester, F.R.S., Jodrell Professor of Zoology in University College, London, Fellow of Exeter College, Oxford, Hon. Sec. of the Marine Biological Association; A. Milnes Marshall, F.R.S., Professor of Zoology in Owens College, Manchester, Member of Council of the Marine Biological Association; W. C. McIntosh, F.R.S., Professor of Natural History in the University of St. Andrews, Vice-President of the Marine Biological Association; H. N. Moseley, F.R.S., Linacre Professor of Human and Comparative Anatomy in the University of Oxford, Chairman of Council of the Marine Bi logical Association; Geo. J. Romanes, F.R.S., Member of Council of the Marine Biological Association; J. Burdon Sanderson, F. R.S.; Waynflete Professor of Physiology in the University of Oxford; E. A. Schäfer, F.R.S., Professor of Physiology in University College, London; P. L. Sclater, F.R.S., Secretary of the Zoological Society, Member of Council of the Marine Biological Association; Adam Sedgwick, F.R.S., Fellow of Trinity College, Cambridge, Member of Council of the Marine Biological Association; C. Stewart, F.L.S., Conservator of the Museum of the Royal College of Surgeons, Member of Council of the Marine Biological Association; D'Arcy W. Thompson, Professor of Zoology in University College, Dundee; Sydney H. Vines, F.R.S. ; W. F. R. Weldon, Fellow of St. John's College, Cambridge; Fran'k Crisp, Vice-President of the Linnean Society, Hon. Treasurer of the Marine Biological Association ; Peter Eade, President, on behalf of the Norfolk and Norwich Naturalists' Society; I. Gurney, Mayor of Norwich, R. E. Burroughes, H. W. Stafford, John B. Pearce, Harry Bullard, S. Gurney Buxton, and John Barwell, Conservators under the Norfol $k$ and Suffolk Fisheries Act, I877, for the City of Norwich; C. Louis Buxton, T. C. Blofeld, and E. Frost, Mayor of Thetford, Conservators for Norfolk; B. F. Grimsey, Mayor of Ipswich, and Lieut.-Col. H. M. Leathes, Conservators for Suffolk; F. B. Archer, Conservator for Lynn; C. J. Greene, Hon. Sec. of the 